\title{
Risk of open angle glaucoma due to tumor necrosis factor alpha gene polymorphisms
}

\author{
Mona Abdel Hamid ${ }^{1}$ Leqaa Moemen ${ }^{1}$, Hany Labib $^{2}$, Hazem Helmy², Tarek Elsergany ${ }^{3}$
}

${ }^{1}$ Medical Biochemistry Unit, Research Institute of Ophthalmology, Giza, Egypt

${ }^{2}$ Ophthalmology Department, Research Institute of Ophthalmology, Giza, Egypt

${ }^{3}$ Clinical Pathology Unit, Research Institute of Ophthalmology, Giza, Egypt

\section{Type of article: Original}

\begin{abstract}
Introduction: Axonal degeneration and retinal ganglion cell apoptosis in glaucoma is associated with tumor necrosis factor alpha (TNF- $\alpha$ ), which is an important pro-inflammatory cytokine. The aim of this study was to determine the association between the risk of open angle glaucoma $(\mathrm{OAG})$ in the Egyptian population and tumor necrosis factor alpha (TNF- $\alpha$ ) gene polymorphisms.

Methods: Sixty OAG patients and 26 healthy unrelated controls were used to analyze TNF- $\alpha$ polymorphism G308A using polymerase chain reaction (PCR) and restriction fragment length polymorphism (RFLP).

Results: the GG genotype was found at a higher frequency in the controls than in the patients, and the AA and GA genotypes were associated strongly with OAG.

Conclusion: In this study, we found that the TNF- $\alpha$ polymorphism G-308A was associated significantly with $\mathrm{OAG}$ in the Egyptian population. However, there is a need for population-based studies with large numbers of subjects. Also, long-term follow up is required to verify the association between TNF- $\alpha$ polymorphism G-308A and glaucoma susceptibility.
\end{abstract}

Keywords: open angle glaucoma, TNF $\alpha 308 \mathrm{G} / \mathrm{A}$ polymorphism

\section{Introduction}

The second leading cause of blindness worldwide is glaucoma, which involves optic neuropathy and the progressive loss of the retinal ganglion cells (RGCs), resulting in visual field defects (1). Depending on its etiology and the dynamics of the aqueous humor, glaucoma is classified into primary and secondary categories. Further classifications of primary glaucoma are primary open angle glaucoma (POAG) and primary angle closure glaucoma (PACG). Two types of POAG are high-tension glaucoma (HTG) and normal tension glaucoma (NTG), while secondary glaucoma has a second type that is referred to as exfoliation glaucoma (EXG). Open angle glaucoma (OAG) includes HTG, NTG, and EXG, and it accounts for about $90 \%$ of the glaucoma experienced by patients (2). OAG has a complex etiology that has yet to be fully understood. The major risk factor for OAG is elevated intraocular pressure (IOP) (3). The main goal of currently available drugs is to lower the IOP; however, the progression of the disease may continue in spite of significant lowering of IOP (4). Obviously, IOP is not the only factor in the pathogenesis of the glaucomatous optic neuropath. Tumor necrosis factor-alpha (TNF- $\alpha$ ) is a proinflammatory cytokine with multiple functions in the immune response, and it belongs to the TNF superfamily of 19 different protein ligands (5). Many studies have suggested strongly the involvement of TNF- $\alpha$ in the etiology of glaucoma (6). Ischemic or pressure-loaded glial cells could produce TNF- $\alpha$, which leads to the loss of oligodendrocytes and the subsequent apoptosis of the RGCs (6). The retina and the head of the optic nerve upregulate the expression of TNF- $\alpha$ and TNF- $\alpha$ receptor-1 (TNF-R1), and the expression of TNF- $\alpha$ and TNF-R1 seems to occur along with the degeneration of the optic nerve (7). TNF- $\alpha$ is upregulated by the increase in IOP, and exogenous TNF- $\alpha$ also can result in the loss of oligodendrocytes and RGCs $(8,9)$. The human TNF- $\alpha$ gene is located on chromosome 6p21.3 (10). Several functional polymorphisms in the promoter region of the TNF- $\alpha$ gene have been

\section{Corresponding author:}

Dr. Leqaa Moemen, Medical Biochemistry Unit, Research Institute of Ophthalmology, Giza, Egypt.

Tel: +20.1001033755, E-mail: leqaa.moemen@yahoo.com

Received: December 04, 2015, Accepted: January 20, 2016, Published: February 2016

iThenticate screening: January 20, 2016, English editing: January 25, 2016, Quality control: January 28, 2016

(C) 2016 The Authors. This is an open access article under the terms of the Creative Commons Attribution-NonCommercialNoDerivs License, which permits use and distribution in any medium, provided the original work is properly cited, the use is non-commercial and no modifications or adaptations are made. 
detected, and they have been associated with the risks of glaucoma. The intensively-studied polymorphism is characterized by a $G$ to A substitution at position -308 , which could increase transcription six to sevenfold (11). Other polymorphisms, including $-238 \mathrm{G} / \mathrm{A},-863 \mathrm{C} / \mathrm{A}$, and $-857 \mathrm{C} / \mathrm{T}$ also have been investigated. Some studies suggested that the TNF- $\alpha-308$ A allele was associated significantly with the increased risk of OAG (12-15), while other studies have shown no significant association (16-18) and even reduced risks of OAG $(19,20)$. Thus, to investigate the role TNF and the risk of glaucoma, many studies have identified higher levels in the aqueous humor (AH) of glaucoma patients than in controls $(21,22)$, but other studies have disagreed with this finding $(23,24)$. In this study, the aim was to study the association of TNF- $\alpha$ polymorphism OAG-308A within the Egyptian population.

\section{Material and Methods}

This case control study included 86 subjects, i.e., 60 patients who had open angle glaucoma (OAG) and a control group that consisted of 26 healthy subjects. All of the patients were given an ophthalmological examination, and the Research Institute of Ophthalmology conducted the laboratory investigations. The ophthalmological examination included best-corrected visual acuity, slit-lamp biomicroscopy using a $90 \mathrm{D}$ lens, gonioscopy using a Goldmann three-mirror contact lens, intraocular pressure (IOP) measurement using Goldman Applanation Tonometry (GAT), photographs of the head of the optic nerve head, and a Humphrey visual field analyzer (24-2 program). We also collected clinical data, including age, gender, diabetes mellitus, history of intraocular surgery, and any antiglaucoma medical regimen. The glaucoma patients had the typical glaucomatous head of the optic nerve and changes in their visual fields.

Blood samples were withdrawn from all of the subjects. The conventional phenol-chloroform method was used to isolate genomic DNA from peripheral blood. Previous studies have described the polymerase chain reaction (PCR) method $(8,9)$. We amplified a 194-bp promoter region where the polymorphism site was located by using primers 5'-AAT GGA AAT AGG TTT TGA GGG T*CA T-3' and 5'-TCT CGG TTT CTT CTC CAT CGC-3' in which $\mathrm{T}^{*}$ was not in the genomic DNA sequence and was introduced to create a potential BspHI site (10). PCR was performed in a total volume of $50 \mu \mathrm{l}$ that contained $5 \mu \mathrm{l}$ of DNA template, $200 \mu \mathrm{M}$ of dNTP, 1 U Taq polymerase in appropriate $10 \mathrm{X}$ buffer, $1.5 \mathrm{mM} \mathrm{MgCl}$, and $25 \mathrm{pM}$ of each of the primers. The cycling conditions we used were: initial denaturation at $94{ }^{\circ} \mathrm{C}$ for $5 \mathrm{~min}, 35$ cycles at $94{ }^{\circ} \mathrm{C}$ denaturation for $30 \mathrm{~s}, 55^{\circ} \mathrm{C}$ annealing for $30 \mathrm{~s}$, and $72{ }^{\circ} \mathrm{C}$ extension for $30 \mathrm{~s}$, and we performed a final extension at $72{ }^{\circ} \mathrm{C}$ for $7 \mathrm{~min}$. The product was electrophoresed in a $1 \%$ (wt/vol) agarose gel, and, after ethidium bromide staining, bands were visualized under ultraviolet (UV) light. To determine the A allele at position -308 , we digested $12.5 \mu \mathrm{l}$ of the PCR product overnight with $10 \mathrm{U}$ of the enzyme, $\mathrm{BspHI}$, at $37{ }^{\circ} \mathrm{C}$ and electrophoresed it in a $2.5 \%$ (wt/vol) agarose gel. This digestion produced an uncut $194 \mathrm{bp}$ fragment when $\mathrm{G}$ was present at -308 position, and two fragments, i.e., 169 and $25 \mathrm{bp}$, were present when A (TNF2) was present.

We analyzed the data using the SPSS statistical package (version 15), and we expressed the data as mean \pm standard deviation for quantitative variables and, for qualitative values, we used numbers and percentages. We used the chisquared test to evaluate the statistical differences between the categorical data, such as gender, genotype distribution of patients, and control groups. The independent sample t test, ANOVA (analysis of variance), and the post-hoc Bonferroni test were used for the normally-distributed qualitative variables, and the non-parametric Mann Whitney test and the Kruskal-Wallis test were used for non-normally-distributed variables. We considered any values of 0.05 or less as being statistically significant.

\section{Results}

There were 86 people in the study, 60 of whom were OAG patients and 26 of whom were healthy controls. The mean age of the OAG patients was $47.3 \pm 12.7$, and the group consisted of 40 males and 20 females. The controls had a mean age of $45.2 \pm 12.3$ and consisted of 17 males and 9 females. The GG genotype was estimated at a frequency of $87 \%$ in the controls and $43 \%$ in the OAG patients with an odds ratio (OR) of 8.95 (95\% confidence interval $[\mathrm{CI}]=4.55-17.81$ (Table 1$)$. The number of heterozygous and homozygous variant subjects was higher in the OAG patients than in the controls $(\mathrm{p}<0.001)$. The AA variant genotype was detected in $25 \%$ of the OAG patients, while it was only $2 \%$ in the controls. The GA heterozygous genotype was detected in $32 \%$ of the OAG patients, but it was detected in only $10 \%$ of the controls. The distribution of allele frequencies (Table 1) of the patients and controls showed that the A allele was more prominent in the OAG patients (41\%) than in the controls $(8 \%)$, and it was related significantly to the severity of the disease, $\mathrm{OR}=8.37(95 \% \mathrm{CI}=4.78-14.81 ; \mathrm{p}<0.001)$. To detect any gender bias, the data of genotype distribution also were stratified with respect to gender (Table 2). We considered the data of males and females separately, and he the GA and AA genotypes were associated significantly 
with OAG, $(\mathrm{p}<0.001$ and $\mathrm{p}<0.001$, respectively). Also, the variant A allele was more prevalent in both the OAG male and female patients than in the controls $(\mathrm{p}<0.001$, respectively). The frequency of the A allele was determined to be essentially the same in both genders $(40 \%$ and $43 \%$, respectively (Table 2$)$.

Table 1. Distribution of TNF- $\alpha \mathrm{G}-308 \mathrm{~A}$ genotype and allele frequency between OAG patients and controls

\begin{tabular}{|c|c|c|c|c|c|}
\hline \multicolumn{2}{|c|}{ Variable } & Controls (26) & OAG (60) & OR $(95 \% \mathrm{CI})$ & $\mathrm{p}$ \\
\hline \multicolumn{2}{|l|}{ Mean age (years) } & $45.2 \pm 12.3$ & $47.3 \pm 12.7$ & & \\
\hline \multirow[t]{2}{*}{ Gender distribution $(\mathrm{n}, \%)$} & Male & $16(64.3 \%)$ & $38(67.2 \%)$ & \multirow[t]{2}{*}{$0.88(0.50-1.54)$} & \multirow[t]{2}{*}{0.6} \\
\hline & Female & $10(35.7 \%)$ & $22(32.8 \%)$ & & \\
\hline \multirow{3}{*}{$\begin{array}{l}\text { Genotypes } \\
(\text { Male + Female }),(n, \%)\end{array}$} & GG & $19(87.3 \%)$ & $26(43.4 \%)$ & $8.95(4.55-17.81)$ & \multirow[t]{3}{*}{$<0.001$} \\
\hline & GA & $4(10.3 \%)$ & $19(32.0 \%)$ & $0.24(0.12-0.51)$ & \\
\hline & AA & $3(2.4 \%)$ & $15(24.6 \%)$ & $0.07(0.02-0.27)$ & \\
\hline \multirow[t]{2}{*}{ Alleles (Male + Female), $(\mathrm{n}, \%)$} & $\mathrm{G}$ & $42(92.5 \%)$ & $70(59.4 \%)$ & \multirow[t]{2}{*}{$8.37(4.78-14.81)$} & \multirow[t]{2}{*}{$<0.001$} \\
\hline & A & $10(7.5 \%)$ & $50(40.6 \%)$ & & \\
\hline
\end{tabular}

Table 2. Distribution ofTNF- $\alpha \mathrm{G}-308 \mathrm{~A}$ genotype and allele frequency between OAG patients and controls according to gender

\begin{tabular}{|c|c|c|c|c|c|}
\hline \multicolumn{2}{|l|}{ Variables } & Controls (26) & OAG (60) & OR $(95 \% \mathrm{CI})$ & $\mathrm{p}$ \\
\hline \multirow[t]{3}{*}{ Genotypes (Male) } & GG & $12(85.2 \%)$ & $16(43.9 \%)$ & $7.35(3.27-16.79)$ & \multirow[t]{3}{*}{$<0.001$} \\
\hline & GA & $3(13.6 \%)$ & $11(32.9 \%)$ & $0.32(0.14-0.75)$ & \\
\hline & AA & $1(1.2 \%)$ & $9(23.2 \%)$ & $0.04(0.001-0.31)$ & \\
\hline \multirow[t]{2}{*}{ Alleles (Male) } & $\mathrm{G}$ & $25(92.0 \%)$ & $42(60.4 \%)$ & $7.53(3.79-15.19)$ & \multirow[t]{2}{*}{$<0.001$} \\
\hline & A & $15(8.0 \%)$ & $29(39.6 \%)$ & & \\
\hline \multirow{3}{*}{$\begin{array}{l}\text { Genotypes } \\
\text { (Female) }\end{array}$} & GG & $7(90.1 \%)$ & $10(42.5 \%)$ & $13.87(3.74-56.25)$ & \multirow[t]{3}{*}{$<0.001$} \\
\hline & GA & $2(4.4 \%)$ & $7(30.0 \%)$ & $0.11(0.02-0.58)$ & \\
\hline & AA & $1(4.4 \%)$ & $5(27.5 \%)$ & $0.12(0.02-0.66)$ & \\
\hline \multirow[t]{2}{*}{ Alleles (Female) } & $\mathrm{G}$ & $18(93.3 \%)$ & $25(57.5 \%)$ & $10.35(3.78-29.81)$ & \multirow[t]{2}{*}{$<0.001$} \\
\hline & $\mathrm{A}$ & $11(6.7 \%)$ & $15(42.5 \%)$ & & \\
\hline
\end{tabular}

Values in parentheses represent percentage, $\mathrm{OR}=$ odds ratio, $\mathrm{CI}=$ confidence interval

\section{Discussion}

Worldwide, glaucoma is the second leading cause of blindness. There is significant scientific evidence pointing to the important role of TNF- $\alpha$ as a mediator of the neuro-degeneration in OAG $(3,5)$. TNF- $\alpha$ is considered to be a neuro-protective component of the immune system because it activates the transcription factor NF- $\mathrm{B}$ by binding to the high-affinity TNF receptor (TNF-R2). This mediates the expression of many genes that are important for the survival of neurons. TNF- $\alpha$ also can act as a neurodegenerative factor by binding to the low-affinity death receptor TNF-R1, thereby inducing the mitochondria-mediated apoptotic pathway (25-29). Thus, the balance between the two pathways determines the survival of the cell, and adverse effects can result from any shift in balance. An increased expression of TNF- $\alpha$ can shift the equilibrium toward TNF-R1 signaling, as occurs in glaucoma, thereby promoting apoptosis of the retinal ganglion cells. Based on this, an anti-glaucoma drug, known as GLC756, was developed to inhibit the release of TNF- $\alpha$ from activated rat mast cells, thereby promoting the survival of the cells. This has been attributed to the potential neuro-protective role of GLC756, giving it a vital role in the treatment of glaucoma (28). In this study, we detected a strong association of GA and AA genotypes with OAG, and this suggested that the A allele has a role in the pathogenesis of the disease. Also, in other studies, a strong association of this polymorphism has been observed, but they performed in patients with primary open-angle glaucoma (POAG), and that had a small number of subjects (29). Although several investigators have been unable to show a significant difference in genotype distribution and allele frequency between patients and control groups, some investigators have successfully detected the functionality of this polymorphism in the reporter gene assays. They have reported significant upregulation, i.e., as much as 500\%, in the constructs of TNF1 and TNF2 alleles (30). Thus, it can be concluded that the transcriptional regulation of TNF- $\alpha$ is essential to overcome the bad effects of overexpression by transcriptional up-regulation. Increased production of TNF, which is associated with G-308A polymorphism, may be important in the initiation of TNF2-associated auto-immune diseases. It may act as a genetic susceptibility factor driven by a high TNF- $\alpha$ expression that would lead to immune responses, thereby causing the onset of various 
diseases (31). In a recent study by Sawada et al. (32), it was determined that the level of TNF- $\alpha$ was significantly higher in the aqueous humor of PEXG patients than in the controls and other glaucoma subtypes, including POAG and normal tension glaucoma. Thus, this is in agreement with the conclusion that TNF- $\alpha$ has a significant involvement in the pathogenesis of the disease. Yu et al. studied the association between the TNF- $\alpha-308 \mathrm{G} / \mathrm{A}$ polymorphism and the risks of glaucoma (33). In their study, they conducted eight investigations of the association between TNF- $\alpha-308 \mathrm{G} / \mathrm{A}$ polymorphism and the risk of glaucoma $(12,19,29)$. The findings of ongoing in vivo studies have supported that finding that TNF- $\alpha$ and TNF-R1 are up-regulated after experimental elevation of IOP. This indicates that there is a potential link between TNF- $\alpha$ and IOP (5). However, no such association was reported by the only two studies in which the association between TNF- $\alpha-308 \mathrm{G} / \mathrm{A}$ polymorphisms and NTG risks was investigated $(18,19)$.

The results of the present study contradicted those of previous studies that have shown no significant association of the TNF- $\alpha$ polymorphism G-308A with OAG $(26,27)$. Agarwal et al. (3) detected that the G to A transition at position -308 results in a six- to sevenfold increase in transcription of TNF- $\alpha$ as compared to normal basal level transcription. Thus, they observed increased levels of TNF. In Razenghinejad et al.'s study (13), they observed a significant association for G-308A polymorphism between OAG patients and controls, and our results agreed with this finding. They also noted that the genotype frequency became statistically insignificant for females when the data were stratified according to gender, and they attributed this observation to the unequal numbers of each gender in the study. In this study, even after gender-wise stratification, it was found that both the genotype frequency and the allele frequency remained significantly associated with the disease. This may be explained by the fact that gender matching was better in this study, and this emphasizes the importance designing genetic association studies very carefully.

\section{Conclusions}

We found the A allele of the TNF- $\alpha$ polymorphism G-308A to be associated strongly with the pathogenesis of OAG. Therefore, we proposed that the GA and AA genotypes of the TNF- $\alpha$ regulatory region can be considered to be genetic markers for the stratification of OAG. Patients with OAG may have higher TNF- $\alpha$ levels in AH than the controls, and this supports the important roles of TNF- $\alpha$ in the development of OAG. Since potential confounders could not be completely ruled out, population-based studies with a larger number of subjects and long-term followup are required to verify the association of TNF- $\alpha$ polymorphism G-308A with the susceptibility to glaucoma. Such studies may provide a new approach for the management of glaucoma and result in improved visual field outcomes.

\section{Acknowledgments:}

The authors thank the Research Institute of Ophthalmology for supporting this research.

\section{Conflict of Interest:}

There is no conflict of interest to be declared.

\section{Authors' contributions:}

All authors contributed to this project and article equally. All authors read and approved the final manuscript.

\section{References}

1) Quigley HA, Broman AT. The number of people with glaucoma worldwide in 2010 and 2020. Br J Ophthalmol. 2006; 90: 262-7. doi: 10.1136/bjo.2005.081224, PMID: 16488940, PMCID: PMC1856963.

2) Distelhorst JS, Hughes GM. Open-angle glaucoma. Am Fam Physician. 2003; 67: 1937-44. PMID: 12751655.

3) Agarwal R, Agarwal P. Glaucomatous neurodegeneration: An eye on tumor necrosis factor-alpha. Indian J Ophthalmol. 2012; 60: 255. doi: 10.4103/0301-4738.98700, PMID: 22824592, PMCID: PMC3442458.

4) Dempsey PW, Doyle SE, He JQ, Cheng G. The signaling adaptors and pathways activated by TNF superfamily. Cytokine Growth Factor Rev. 2003; 14: 193-209. doi: 10.1016/S1359-6101(03)00021-2.

5) Tezel G. TNF-alpha signaling in glaucomatous neurodegeneration. Prog Brain Res. 2008; 173: 409-21. doi: 10.1016/S0079-6123(08)01128-X.

6) Tezel G, Wax MB. Increased production of tumor necrosis factor-alpha by glial cells exposed to simulated ischemia or elevated hydrostatic pressure induces apoptosis in cocultured retinal ganglion cells. J Neurosci. 2000; 20: 8693-700. PMID: 11102475. 
7) Yuan L, Neufeld AH. Tumor necrosis factor-alpha: a potentially neurodestructive cytokine produced by glia in the human glaucomatous optic nerve head. Glia. 2000; 32: 42-50. doi: 10.1002/10981136(200010)32:1<42::AID-GLIA40>3.0.CO;2-3.

8) Yan X, Tezel G, Wax MB, Edward DP. Matrix metalloproteinases and tumor necrosis factor alpha in glaucomatous optic nerve head. Arch Ophthalmol. 2000; 118: 666-73. doi: 10.1001/archopht.118.5.666, PMID: 10815159.

9) Nakazawa T, Nakazawa C, Matsubara A, Noda K, Hisatomi T, She H, et al. Tumor necrosis factor-alpha mediates oligodendrocyte death and delayed retinal ganglion cell loss in a mouse model of glaucoma. $\mathrm{J}$ Neurosci. 2006; 26: 12633-41. doi: 10.1523/JNEUROSCI.2801-06.2006, PMID: 17151265.

10) Hajeer $\mathrm{AH}$, Hutchinson IV. Influence of TNFalpha gene polymorphisms on TNFalpha production and disease. Hum Immunol. 2001; 62: 1191-9. doi: 10.1016/S0198-8859(01)00322-6.

11) Agarwal P, Oldenburg MC, Czarneski JE, Morse RM, Hameed MR, Cohen S, et al. Comparison study for identifying promoter allelic polymorphism in interleukin 10 and tumor necrosis factor alpha genes. DiagnMolPathol. 2000; 9: 158-64. doi: 10.1097/00019606-200009000-00006, PMID: 10976723.

12) Al-Dabbagh NM, Al-Dohayan N, Al-Asmari A, Arfin M, Tariq M. Association of TNF- $\alpha$ and TNF- $\beta$ Gene Polymorphisms with Primary Open Angle and Primary Angle Closure Glaucoma. In: Tomas Kubena, editor. The Mystery of Glaucoma. InTech; 2011; 229-56. doi: 10.5772/19057.

13) Razeghinejad MR, Rahat F, Kamali-Sarvestani E. Association of TNFA -308 G/A and TNFRI +36 A/G gene polymorphisms with glaucoma. Ophthalmic Res. 2009; 42: 118-24. doi: 10.1159/000226108, PMID: 19556827.

14) Khan MI, Micheal S, Rana N, Akhtar F, den Hollander AI, Ahmed A, et al. Association of tumor necrosis factor alpha gene polymorphism G-308A with pseudoexfoliative glaucoma in the Pakistani population. Mol Vis. 2009; 15: 2861-7. PMID: 20029655, PMCID: PMC2796874.

15) Lin HJ, Tsai FJ, Chen WC, Shi YR, Hsu Y, Tsai SW. Association of tumour necrosis factor alpha -308 gene polymorphism with primary open-angle glaucoma in Chinese. Eye (Lond). 2003; 17: 31-4. doi: 10.1038/sj.eye.6700227, PMID: 12579167.

16) Mossböck G, Renner W, El-Shabrawi Y, Faschinger C, Schmut O, Wedrich A, et al. TNF-alpha -308 G>A and $-238 \mathrm{G}>\mathrm{A}$ polymorphisms are not major risk factors in Caucasian patients with exfoliation glaucoma. Mol Vis. 2009; 15: 518-22. PMID: 19279689, PMCID: PMC2654045.

17) Mossböck G, Weger M, Moray M, Renner W, Haller-Schober EM, Mattes D, et al. TNF-alpha promoter polymorphisms and primary open-angle glaucoma. Eye (Lond). 2006; 20: 1040-3. doi: 10.1038/sj.eye.6702078, PMID: 16138112.

18) Funayama $T$, Ishikawa K, Ohtake $Y$, Tanino $T$, Kurosaka D, Kimura I, et al. Variants in optineurin gene and their association with tumor necrosis factor-alpha polymorphisms in Japanese patients with glaucoma. Invest Ophthalmol Vis Sci. 2004; 45: 4359-67. doi: 10.1167/iovs.03-1403, PMID: 15557444.

19) Fan BJ, Liu K, Wang DY, Tham CC, Tam PO, Lam DS, et al. Association of polymorphisms of tumor necrosis factor and tumor protein p53 with primary open-angle glaucoma. Invest Ophthalmol Vis Sci. 2010; 51: 4110-6. doi: 10.1167/iovs.09-4974, PMID: 20357201.

20) Tekeli O, Turacli ME, Egin Y, Akar N, Elhan AH. Tumor necrosis factor alpha-308 gene polymorphism and pseudoexfoliation glaucoma. Mol Vis. 2008; 14: 1815-8. PMID: 18852869, PMCID: PMC2565691.

21) Chua J, Vania M, Cheung CM, Ang M, Chee SP, Yang H, et al. Expression profile of inflammatory cytokines in aqueous from glaucomatous eyes. Mol Vis. 2012; 18: 431-8. PMID: 22355254, PMCID: PMC3283212.

22) Balaiya S, Edwards J, Tillis T, Khetpal V, Chalam KV. Tumor necrosis factor-alpha (TNF-alpha) levels in aqueous humor of primary open angle glaucoma. ClinOphthalmol. 2011; 5: 553-6. doi: 10.2147/opth.s19453.

23) Takai Y, Tanito M, Ohira A. Multiplex cytokine analysis of aqueous humor in eyes with primary openangle glaucoma, exfoliation glaucoma, and cataract. Invest Ophthalmol Vis Sci. 2012; 53: 241-7. doi: 10.1167/iovs.11-8434, PMID: 22159018.

24) Higgins JP, Thompson SG. Quantifying heterogeneity in a meta-analysis. Stat Med. 2002; 21: 1539-58. doi: 10.1002/sim.1186, PMID: 12111919.

25) Tobias A. Assessing the influence of a single study in the meta-analysis estimate. Stata Tech Bull. 1999; 47: $15-7$.

26) Harbord RM, Egger M, Sterne JA. A modified test for small-study effects in meta-analyses of controlled trials with binary endpoints. Stat Med. 2006; 25: 3443-57. doi: 10.1002/sim.2380, PMID: 16345038. 
27) Zeng T, Guo FF, Zhang CL, Song FY, Zhao XL, Xie KQ. A meta-analysis of randomized, double-blind, placebo-controlled trials for the effects of garlic on serum lipid profiles. J Sci Food Agric. 2012; 92: 1892902. doi: 10.1002/jsfa.5557, PMID: 22234974.

28) Cui G, Wang H, Li R, Zhang L, Li Z, Wang Y, et al. Polymorphism of tumor necrosis factor alpha (TNFalpha) gene promoter, circulating TNF-alpha level, and cardiovascular risk factor for ischemic stroke. J Neuroinflammation. 2012; 9: 235. doi: 10.1186/1742-2094-9-235, PMID: 23050663, PMCID: PMC3521196.

29) Bozkurt B, Mesci L, Irkec M, Ozdag BB, Sanal O, Arslan U, et al. Association of tumour necrosis factoralpha -308 G/A polymorphism with primary open-angle glaucoma. Clin Experiment Ophthalmol. 2012; 40: e156-62. doi: 10.1111/j.1442-9071.2011.02595.x, PMID: 21575121.

30) Wang CY, Shen YC, Wei LC, Lin KH, Feng SC, Yang YY,. Polymorphism in the TNF-alpha(-863) locus associated with reduced risk of primary open angle glaucoma. Mol Vis. 2012; 18: 779-85. PMID: 22509108, PMCID: PMC3324355.

31) Kuchtey J, Rezaei KA, Jaru-Ampornpan P, Sternberg P, JrKuchtey RW. Multiplex cytokine analysis reveals elevated concentration of interleukin-8 in glaucomatous aqueous humor. Invest Ophthalmol Vis Sci. 2010; 51: 6441-7. doi: 10.1167/iovs.10-5216, PMID: 20592224 , PMCID: PMC3055764.

32) Sawada H, Fukuchi T, Tanaka T, Abe H. Tumor necrosis factor-alpha concentrations in the aqueous humor of patients with glaucoma. Invest Ophthalmol Vis Sci. 2010; 51: 903-6. doi: 10.1167/iovs.09-4247, PMID: 19737888.

33) $\mathrm{Yu}$ QQ, Yao Y. A detailed meta-analysis shows no association between TNF-alpha -308G/A polymorphism and different forms of glaucoma. Ophthalmic Res. 2012; 47: 47-51. doi: 10.1159/000328631, PMID: 21701244. 